\title{
GITAR HEBAT (GERAKAN IBU PINTAR HEMOGLOBIN MENINGKAT) DI DESA SIDOREJO KECAMATAN SEKAMPUNG UDIK LAMPUNG TIMUR
}

\author{
Vida Wira Utami ${ }^{1}$, Yulistiana Evayanti ${ }^{2}$ \\ 1,2 Prodi Kebidanan Malahayati \\ vida@malahayati.ac.id, yulistianaevayanti@gmail.com
}

\begin{abstract}
ABSTRAK
Menurut WHO (2013), berkisar 20\% dan $89 \%$ ibu hamil mengalami kejadian anemia dengan menetapkan Hemoglobin $11 \mathrm{~g} \%$ sebagai dasarnya. Vitamin C dapat meningkatkan penyerapan besi non heme sebesar empat kali lipat dan dengan jumlah $200 \mathrm{mg}$ akan meningkatkan absorpsi besi sedikitnya 30\% (Goodman, 2008). Buah jambu biji mengandung asam askorbat 2 kali lipat dari jeruk yaitu sekitar $87 \mathrm{mg} / 100$ gram jambu biji. Tanaman jambu biji mudah ditemukan dan lebih ekonomis, sehingga hal tersebut menjadi salah satu alasan pemilihan bahan menjadi produk untuk intervensi. Selain itu, jambu biji merah juga kaya akan vitamin dan mineral. Kandungan vitamin $C$ jambu biji mencapai puncaknya menjelang matang.
\end{abstract}

Kata Kunci : Jambu Biji Merah, Kadar Hemoglobin, Ibu Hamil

\section{ABSTRACT}

According to WHO (2013), around $20 \%$ and $89 \%$ of pregnant women experience anemia by setting hemoglobin $11 \mathrm{~g} \%$ as the basis. Vitamin C can increase the absorption of non-heme iron by four times and with an amount of $200 \mathrm{mg}$ will increase the absorption of iron by at least 30\% (Goodman, 2008). Guava fruit contains twice as much ascorbic acid as oranges, which is about 87 $\mathrm{mg} / 100$ grams of guava. Guava plants are easy to find and more economical, so this is one of the reasons for choosing materials to become products for intervention. In addition, red guava is also rich in vitamins and minerals. The vitamin C content of guava reaches its peak before it is ripe.

Keywords: Red Guava, Hemoglobin Levels, Pregnant Women

\section{PENDAHULUAN}

Anemia adalah suatu keadaan dengan kadar hemoglobin $(\mathrm{Hb})$ darah yang lebih rendah dari pada normal sebagai akibat ketidakmampuan jaringan pembentuk sel darah merah dalam produksinya guna mempertahankan kadar hemoglobin pada tingkat normal (Andriani dan Wirjatmadi, 2012). Anemia jika tidak diatasi segera dapat berdampak buruk bagi ibu dan janin, serta meningkatkan Angka Kematian Ibu (AKI) dan Angka Kematian Bayi $(A K B)$. Angka Kematian Ibu (AKI) di Indonesia adalah yang tertinggi bila dibandingkan dengan negara-negara ASEAN lainnya. (Manuaba, 2012). Berdasarkan hasil Analisis Survey Demografi Kesehatan Indonesia (SDKI) 2012 Angka Kematian Ibu (AKI) di Indonesia masih tinggi yaitu 359/100.000 KH. Penyebab utama kematian ibu secara langsung adalah perdarahan 28\%, eklampsia $24 \%$, dan infeksi $11 \%$. Penyebab secara tidak langsung adalah anemia 51\% (Profil Dinas Kesehatan Provinsi Lampung,2017) 
Penyebab terbanyak anemia defisiensi zat besi yaitu karena rendahnya masukan zat besi yang berasal dari makanan, serta rendahnya tingkat penyerapan zat besi dari makanan. Rendahnya tingkat penyerapan zat besi disebabkan oleh komposisi menu makanan masyarakat yang lebih banyak mengandung faktor - faktor yang dapat menghambat penyerapan zat besi seperti serat, fitat, maupun tannin (Tarwoto dan Wasnidar,2013).

Vitamin $C$ dapat meningkatkan penyerapan besi non heme sebesar empat kali lipat dan dengan jumlah $200 \mathrm{mg}$ akan meningkatkan absorpsi besi sedikitnya 30\% (Goodman, 2008). Buah jambu biji mengandung asam askorbat 2 kali lipat dari jeruk yaitu sekitar 87 mg/100 gram jambu biji. Tanaman jambu biji mudah ditemukan dan lebih ekonomis, sehingga hal tersebut menjadi salah satu alasan pemilihan bahan menjadi produk untuk intervensi. Selain itu, jambu biji merah juga kaya akan vitamin dan mineral. Kandungan vitamin C jambu biji mencapai puncaknya menjelang matang. Jambu biji merah memiliki rasa yang lebih kelat dibandingkan jambu dengan daging putih.

Buah jambu biji merah mengandung serat serta kapasitas antioksidan penting seperti polifenol, karoten dan vitamin C (Suarez, 2018). Buah Jambu biji merah aman dikonsumsi oleh ibu hamil dan ibu menyusui ketika dimakan sebagai makanan bukan sebagai obat.

\section{MASALAH}

Alasan kami memilih tempat kegiatan di Desa Ini karena di desa ini terdapat ibu hamil yang mengalami anemia yang belum mengetahui manfaat.jus jambu biji merah terhadap peningkatan kadar hemoglobin ibu hamil di desa Sidorejo Lampung Timur tahun 2021.

\section{METODE}

Kegiatan telah dilaksanakan di desa Sidorejo Lampung Timur pada tanggal 26 Maret 2021 Jam 10.00 WIB hingga selesai . Kegiatan dilakukan dengan memberikan edukasi berupa penyuluhan dengan metode ceramah. Waktu yang diperlukan dalam penyampaian materi adalah 40 menit, Tahap akhir dari kegiatan tersebut adalah mengukur kembali tingkat pengetahuan lansia dengan memberikanpertanyaan diberikan secara lisan.

\section{HASIL DAN PEMBAHASAN}

Rangkaian kegiatan penyuluhan kepada lansia di desa Sidorejo Lampung Timur tahun 2021 . berjalan dengan lancar tanpa kendala.Penyuluhan $i$ manfaat.jus jambu biji merah terhadap peningkatan kadar hemoglobin ibu hamil di ikuti 20 Ibu hamil Peserta cukup antusias terhadap materi yang diberikan. Umpan balik yang di berikan pun cukup positif. Terdapat beberapa pertanyaan dan sanggahan dari peserta penyuluhan terkait materi.Materi penyuluhan dapat diterima dengan baik. Metode yang digunakan adalah ceramah, tanya jawab dan evaluasi dengan menanyakan kembali apa yang sudah di jelaskan. 


\section{KESIMPULAN}

1. Ibu hamil sudah memahami bahaya tentang anemia pada kehamilan.

2. Semua ibu hamil mengatakan akan mengkonsumsi tablet fe selama kehamilannya.

3. Ibu hamil telah mengkonsumsi jus jambu merah selama 7 hari.

4. Memeriksa $\mathrm{Hb}$ ibu hamil setelah mengkonsumsi jus jambu merah selama 7 hari dan didapatkan ada peningkatan $\mathrm{Hb}$ pada ibu hamil yang mengalami anemia sebesar $0,3-0,5 \%$.

\section{DAFTAR PUSTAKA}

Diana $^{1}$, A., Yuviska, I. A., Iqmy, L. O., \& Evayanti, Y. (2020). Penyuluhan tentang bahaya seks bebas mempengaruhi pengetahuan remaja.

Dinas Kesehatan Provinsi Lampung. (2017). Profil Kesehatan Provinsi Lampung Tahun 2013.

Megawati. (2020). Pengaruh Pemberian Jus Jambu Biji Merah Dan Kurma Terhadap Peningkatan Kadar Hemoglobin Pada Ibu Hamil Trimester lii Di Praktik Mandiri Bidan Indrawaty Tahun 2020

Proverawati, Atikah. (2018). Anemia dan Anemia Kehamilan. Yogyakarta : Nuha Medika.

Utami, V. W., \& Yuliasari, D. (2020). SOSIALISASI PROSES PERSALINAN YANG AMAN DI ERA PANDEMI COVID-19. Jurnal Perak Malahayati, 2(2), 105108.

Utami, V. W., \& Wulandari, D. R. (2021). PENYULUHAN TENTANG CARA MENGKONSUMSI MADU YANG BENAR UNTUK MENINGKATKAN KADAR HAEMOGLOBIN (Hb) PADA IBU HAMIL DI DESA JATI BARU LAMPUNG SELATAN. JURNAL PERAK MALAHAYATI, 3(1), 21-28.

Yantina, Yuli. (2017). Pengaruh Komsumsi Jambu Biji Merah Terhadap Pengingkatan Kadar Hemoglobin pada Ibu Hamil Trimester I di BPS Lolita Puspita Sari Punggur Lampung Tengah tahun 2017 